Таке саме питання було задане студентам. Випускники КПІ ДВНЗ «Криворізький національний університет» головним мотивом назвали, як і вчителі, інтерес та любов до дітей - 50 \% та 35,7 \% вибору. Значний відсоток студентів (45,0\% випускників музичнопедагогічного факультету та 28,9 \% випускників педагогічного факультету) уважає роботу творчою й цікавою. Однак, на факультетах малий відсоток упевнених у своїх можливостях забезпечити позитивний вплив на підростаюче покоління (відповідно 20,0 \% та 15,3\%). Особливо турбує той факт, що все-таки 3-поміж випускників $є$, хоч і незначна кількість (відповідно 5,0 \% та 8,5 \%), тих, кого робота у школі не приваблює.

Проаналізувавши відповіді респондентів, зазначимо, що проблема мотивації професійної діяльності перебуває в тісному зв'язку з ефективністю відбору абітурієнтів та подальшим формуванням стійкого позитивного ставлення до обраної професії. За умови, коли має місце чинник випадковості, результатом може бути або відплив молодих учителів зі шкіл, або негативні результати педагогічної діяльності.

Отже, можна стверджувати, що результат педагогічної діяльності стане ефективнішим, якщо буде задіяно весь спектр позитивної мотивації. Квінтесенцією такої роботи має стати розвиток мотиваційної оріснтації студента на успішність навчальної діяльності 3 наголосом на її процес та результат, а не на єдиний метод «залякування» неотриманням бажаної оцінки, заліку, стипендії, закінчення курсу чи освіти в цілому з боку викладачів та адміністрації і відповідну реакцію студента - будь що уникнути таких «неприємностей».

\title{
Література
}

1. Балакірєва О. Ціннісні орієнтації молодого покоління / О. Балакірєва, О. Яременко // Молодь у дзеркалі соціології. - К. : УІСД, 2001. - С. 38-47. 2. Борис I. Мотиваційна сфера як проблемний чинник поведінки / І. Борис // Психологія і суспільство. - Тернопіль: Інститут експериментальних систем освіти. - 2002. - № 2. - С. 48-57. 3. Ильин Е. П. Мотивация и мотивы : [учебник] /Е. П. Ильин. - М. : Питер, $2002-508$ с. 4. Маслоу А. Мотивация и личность / А. Маслоу. - М. : Питер, 2007. - 351 с. 5. Скляр П. Мотивація навчальної діяльності студентів / П. Скляр // Соціальна психологія. - 2004. - № 5 (7). - С. 95-108. 6. Langveld M. I. The Psycholoqic of Teachers and the Teachering Profession. State University of Utrecht. The Ycar Boor of Education, 1963.

УДК $371.134: 373.3$

I. O. Талаш, кандидат філол. наук, Криворізький педагогічний інститут ДВНЗ «Криворізький національний університет»

\section{АКТИВІЗАЦІЯ ПІЗНАВАЛЬНОЇ ДІЯЛЬНОСТІ МАЙБУТНІХ УЧИТЕЛІВ ПОЧАТКОВИХ КЛАСІВ}

Талаш І. О. Активізація пізнавальної діяльності майбутніх учителів початкових класів.

У статті зроблено спробу окреслити шляхи активізації пізнавальної діяльності студентів психолого-педагогічного факультету у процесі впровадження модульно-рейтингової технології навчання.

Ключові слова: пізнавальна активність, пізнавальні мотиви, модуль, блок, модульно-рейтингова технологія.

Талаш И. А. Активизация познавательной деятельности будущих учителей начальных классов.

В статье осуществлена попытка определить пути активизации познавательной деятельности студентов психолого-педагогического факультета в процессе внедрения модульно-рейтинговой технологии обучения.

Ключевые слова: познавательная активность, познавательные мотивы, модуль, блок, модульнорейтинговая технология.

Talash I. O. Activization of cognitive activity of future primary school teachers. 
In article attempt to define a way of activization of cognitive activity of students of psychological and pedagogical faculty in the course of introduction of modular and rating technology of training is carried out.

Key words: cognitive activity, cognitive motives, module, block, modular and rating technology.

Підвищення якості вищої освіти є нагальною проблемою не лише для закладів освіти України, але й для європейських ВНЗ. Водночас важливою постає проблема підвищення пізнавальної активності студентів, інтенсивного залучення їх до процесу безперервної самоосвіти. Очевидно, що в межах традиційної лекційно-семінарської системи з огляду на iii специфіку ці проблеми розв'язати досить складно. Нині єдиною альтернативою традиційній лекційно-семінарській системі освіти $є$ модульно-рейтингова технологія, яка в межах Болонського процесу активно впроваджується в переважній більшості вищих навчальних закладах Європи, Росії, України. Конференція європейських міністрів освіти, яка поклала початок Болонському процесу, відбулася ще в 1999 році в італійському місті Болоньї. Україна приєдналася до Болонського процесу 19 травня 2005 року. I хоча Болонський процес триває понад 10 років (в Україні - 7 років), нині не розв'язаною залишаються низка питань, зокрема, визначення обсягу кредитів навчальних дисциплін, методика оцінювання навчальних досягнень студентів, шляхи адаптації модульнорейтингової технології до специфіки фахової підготовки майбутніх учителів початкової школи, підвищення їх пізнавальної активності, формування мотивів і вмінь до самоосвіти протягом навчання у ВНЗ і в процесі подальшої професійної діяльності. Тому актуальною $\epsilon$ проблема активізації пізнавальної діяльності студентів психолого-педагогічних факультетів у процесі впровадження модульно-рейтингової технології в педагогічних BH3.

Теоретичні основи модульного навчання, започаткованого в англомовних країнах як удосконалений варіант програмованого навчання, активно розробляються з 60 -х років ХХ століття до сьогодні такими науковцями: О. Аніщенко, О. Безносюком, С. Гончаровим, Н. Гузій, В. Гуриним, Т. Козак, В. Нагаєвим, Дж. Расселом, В. Стрельніковим, П. Юцявичене, Н. Яковець та ін. Досить грунтовно розроблено методичні рекомендації щодо структурування модульних програм з навчальних дисциплін, що викладаються для студентів економічних спеціальностей (С. Гончаров, В. Гурин, В. Нагаєв, І. Сікорський). Однак, методичних рекомендацій із організації модульно-рейтингового навчання в педагогічних вищих навчальних закладах обмаль (праці Л. Кондрашової, Н. Шиян), що вимагають подальшого розроблення, апробації та вдосконалення.

Проблеми активізації пізнавальної діяльності студентів розглядали такі науковці, як: О. Волкова (технологічна організація навчально-пізнавальної діяльності), Н. Жукова (рефлексія як механізм регуляції мислення студентів), В. Ільїн (підвищення системності в педагогічній підготовці студентів), Є. Машбиць (психологічні основи управління навчальною діяльністю), І. Морозова (чинники продуктивності пізнавальної діяльності), Е. Юдин (інтенсифікація навчального процесу) та ін. Водночас залишаються остаточно нерозв'язаними питання методики впровадження модульно-рейтингової технології під час викладання дисциплін педагогічного циклу й активізації пізнавальної діяльності студентів на заняттях і в процесі самостійної підготовки.

Mema cmammi - визначити педагогічні умови активізації пізнавальної діяльності студентів у процесі вивчення дисциплін педагогічного циклу; окреслити особливості використання засобів модульно-рейтингової технології у процесі фахової підготовки майбутніх учителів початкових класів.

Основна мета впровадження модульного навчання - досягнення переходу студента на позиції дійсного суб'єкта навчальної діяльності, здатного активно й самостійно, 3 урахуванням вимог часу та власних можливостей, розв'язувати навчальні, а надалі й виробничі завдання. Реалізація цієї мети передбачає зосередження уваги насамперед на соціально-психологічних і психолого-педагогічних детермінантах успішності навчання. 
Соціально-психологічні детермінанти зумовлені віковими особливостями студентства, адже у період навчання у вищому навчальному закладі відбувається перехід від зрілої юності (18-20 років) до ранньої зрілості (20-30 років). У період зрілої юності відбувається суттєва перебудова особистості, зумовлена змінами соціальної ситуації розвитку необхідністю професійного самовизначення людини. Вищий навчальний заклад $\epsilon$ найважливішим етапом оволодіння професією, початком професійного становлення. Разом із тим, результати анкетування першокурсників засвідчують, що не всі студенти свідомо обрали професію вчителя початкових класів, відповідно, це негативно впливає в подальшому на рівень пізнавальної активності студентів. Тому викладачам необхідно проводити широку профорієнтаційну роботу з першокурсниками, розкриваючи специфіку й особливості вчительської професії, окреслюючи перспективи й етапи професійного становлення в процесі навчання. Тим більше, що навчальні плани першого курсу передбачають опанування студентами лише загальних, ввідних дисциплін, які слабко відображають сутність професійної діяльності вчителя. Однак, ці дисципліни є базовими для спеціальних курсів, які студенти вивчатимуть на старших курсах. Відповідно, викладачу варто не просто окреслити зв'язок цієї дисципліни 3 іншими галузями наукового знання, а конкретизувати зв'язок дисципліни, що вивчається, з тими, які студенти будуть опановувати в подальшому. На старших курсах можна запропонувати самим студентам визначити зв'язки між дисциплінами, які вони вже опанували. Задля профорієнтації доцільно було б, на нашу думку, запрошувати першокурсників на звітні конференції студентів-старшокурсників з педагогічної практики (літньої - в оздоровчих таборах і виробничої - у школах).

У період ранньої дорослості (або молодості) актуальною проблемою для молодої людини постає опанування багатьма соціальними ролями, зокрема, роллю дружини / чоловіка, мами / батька. У зв'язку з цим варто зорієнтувати студентів на те, що їх психологічна та педагогічна компетентність $є$ запорукою успішної реалізації себе не лише в професійному, а й особистісному житті.

Потужним соціальним регулятором активізації пізнавальної діяльності студентів, головним механізмом іiі інтенсифікації $\epsilon$ суб'єктність. Як справедливо зауважує О. Волкова, суб'єктність виражає певну позицію особистості та розкриває ті іiі характеристики, які визначають ставлення особистості до діяльності. Атрибутами суб’єктності, що впливають на активізацію пізнавальної діяльності, є: активність, свідомість, відповідальність, висока самооцінка, готовність до саморозвитку й самоуправління. Для усвідомлення себе суб’єктом власної діяльності потрібна сформована специфічна внутрішня позиція особистості. Б. Братусь, описуючи внутрішній план особистості, здатної до діалогічної взаємодії, визначив такі властивості: ставлення до іншого як до самоцінної особистості, що уособлює нескінченний потенціал роду людського; здатність до децентрації, самовіддачі й любові як реалізації цього ставлення; творчий характер життєдіяльності; потреба в позитивній свободі; здатність до вільного волевиявлення; можливість самопроектувати майбутнє; віра у здійснення запланованого; внутрішня відповідальність перед собою та іншими; прагнення до набуття загального сенсу власного життя.

Слід зазначити, що ці якості частково сформовані у студентів, які приходять на навчання до ВНЗ, однак, ступінь сформованості різний, тому викладач повинен цілеспрямовано протягом навчання формувати ці якості і властивості особистості, адже від цього залежить успішність професійного становлення загалом, і зокрема, рівень пізнавальної активності студента.

Під час організації пізнавальної діяльності студентів слід ураховувати, що провідним поміж чотирьох видів пізнавальної мотивації, виокремлених С. Рубінштейном, $\epsilon$ визначений інтерес до предмета, пов'язаного певним чином з обраною майбутньою практичною діяльністю. Відповідно, мотивація набуває переважно процесуального характеру (студент зорієнтований на опанування способами професійної діяльності). 
Наукові знання є змістом пізнавальної потреби студентів. Водночас спостерігається пізнавальна інертність студентів, намагання на семінарських заняттях обмежитися репродуктивним викладом самостійно опрацьованого матеріалу, пасивність в опрацюванні першоджерел, невміння узагальнювати й систематизувати наукові факти, здійснювати психолого-педагогічний аналіз явищ, що спостерігають під час педагогічної практики. На нашу думку, ці недоліки зумовлені перехідним станом системи вищої освіти від традиційної до модульно-рейтингової технології навчання.

Центральною категорією модульної системи навчання є поняття «модуль», під яким розуміється відносно самостійна частина навчального процесу (певний функціональний вузол і цілісний блок інформації), яка містить одне чи кілька близьких за змістом і фундаментальних за значенням понять, законів і принципів. У цьому розумінні принцип модульності щодо змісту навчального матеріалу $є$ похідним від відомого психологічного положення про те, що цілісність, структурованість і компактність матеріалу, що пропонується для засвоєння, є головною умовою поглибленого осмислення його i найповнішого засвоєння за одиницю часу. При цьому доцільно формувати структуру заняття так, щоб воно містило теоретичну й практичну частини. У теоретичній частині повинні міститися фундаментальні знання, що розкривають теоретичні основи педагогічної професії і педагогічної діяльності. Практична частина має бути присвячена творчому розв'язанню навчальних завдань, наприклад, розгляд і вирішення педагогічних ситуацій, удосконалення фрагментів уроків відповідно до визначених умов.

Нам імпонує варіант структури заняття, розроблений Л. Кондрашовою. Науковець пропонує, щоб структура кожного заняття містила кілька блоків, а саме: інформаційнодискусійний (передбачає засвоєння й обговорення теоретичних понять); практичноперетворювальний (студенти «занурюються» у різноманітні види навчально-пізнавальної діяльності); рефлексивний (передбачає роботу студентів із власним досвідом, самоідентифікацію із ситуацією взаємодії, що склалася, самооцінку досягнень із теми); блок вільного обміну інформацією (оцінка навчальних досягнень, загального враження від заняття); блок самоосвіти (самостійне вивчення літературних джерел з проблеми заняття) [5, с. 383-384]. Слід зауважити, що для активізації пізнавальної діяльності студентів під час опрацювання теоретичних положень завдання інформаційно-дискусійного блоку повинні мати досить чітке й конкретне формулювання, яке має не лише проблемний характер, а й містить елементи інструктажу (вказівку на спосіб виконання завдання). Доречними будуть завдання на створення порівняльних таблиць, узагальнюючих схем на матеріалі, що вивчався протягом модуля або кількох блоків у межах модуля. Це дає змогу студентам переосмислити теоретичний матеріал, побачити зв'язки між різними блоками, усвідомити логіку структурування навчального матеріалу в межах модуля. Крім того, завдання інформаційно-перетворювального блоку повинні орієнтувати студентів на реалізацію міжпредметних зв'язків. Наприклад, під час опанування дисципліни «Педагогічні технології в початковій школі» доречним буде таке завдання: «Визначити концептуальну основу педагогічної технології». Щоб дати відповідь на це запитання, студенти повинні встановити міжпредметні зв'язки з такими дисциплінами: філософія, загальна педагогіка, історія педагогіки, загальна психологія, педагогічна психологія.

Важливо зазначити, що студентам слід показати зразки опрацювання теоретичного матеріалу, продемонструвати процес аналізу й узагальнення, структурування наукового знання. Відповідні можливості й умови для реалізації цієї діяльності є у лектора. Адже за вимогами модульного навчання, лекції повинні мати оглядовий характер, тому теоретичний матеріал повинен бути максимально сконцентрований і мати інтегрований характер. Ущільнення матеріалу може ефективно відбуватися шляхом його структурування, укрупнення в інформаційні блоки. Відповідно, лектор переходить від традиційного читання лекції до інтерактивної взаємодії з аудиторією, пропонуючи разом розв'язати проблемне запитання, подумати над тим, як можна узагальнити викладені факти, протягом лекції заповнити матрицю багатоекранної схеми тощо. Таким чином на 
лекції опрацьовуються ті способи структурування теоретичного матеріалу, які студенти зможуть використати в процесі підготовки до практичного заняття.

Опрацювання першоджерел має набувати характеру взаємообміну цікавою й корисною інформацією. Ініціатором цієї взаємодії повинен виступати сам викладач, який спочатку пропонує цікавий уривок 3 твору видатного педагога, а після того, як студенти ознайомляться 3 твором (або іншими творами цього педагога за вибором), пропонує обмінятися враженнями. Важливою педагогічною умовою $\epsilon$, по-перше, щире захоплення певними педагогічними ідеями (методами, прийомами тощо) самого викладача, уміння показати студентам актуальність праць видатних педагогів; по-друге, створення відповідної емоційної атмосфери під час ознайомлення з першоджерелами, і лише потім перехід до глибокого їх аналізу.

Оскільки модульно-рейтингова технологія зорієнтована передусім на специфічне структурування змісту навчальної дисципліни, але відкрита для використання продуктивних методів навчання, зокрема елементів інших інноваційних технологій, то форми й методи опанування навчальним матеріалом у практично-перетворювальному блоці викладач обирає відповідно до мети і завдань заняття, специфіки навчального матеріалу, підготовленості й здібностей студентів. При цьому слід пропонувати різні форми й методи роботи, варіанти завдань, щоб студенти могли обирати найбільш зручний для себе спосіб опанування матеріалу. На цьому етапі, на нашу думку, найбільш ефективними є різні види групової роботи, оскільки дають можливість студентам обговорити результати виконання практичного завдання, порівняти їх, зробити відповідні висновки й узагальнення, з'ясувати проблемні ситуації, обмінятися думками тощо. Крім того, саме у процесі групової діяльності вдосконалюються комунікативні вміння, розвивається рефлексія. Групова форма організації навчальної діяльності стимулює пізнавальну активність кожного студента, адже він позбавлений можливості просто «відсидіти» пару, до того ж дозволяє використовувати досить широкий спектр методів: проблемно-пошукових, інтерактивних, творчих.

Отже, активізація пізнавальної діяльності студентів буде ефективною за таких умов: модульно-блочного структурування навчального матеріалу; інтеграції навчального матеріалу, реалізації міжпредметних зв'язків; використання різноманітних форм і методів опанування навчальною дисципліною, що мають проблемно-пошуковий, інтерактивний, творчий характер; розвитку суб'єктності особистості студента; систематичного проведення профорієнтаційної роботи серед студентства; активного залучення викладача до навчально-виховного процесу.

\section{Література}

1. Аніщенко О. В. Сучасні педагогічні технології: [курс лекцій] / О. В. Аніщенко, Н. І. Яковець. Ніжин : Видавництво НДУ ім. М. Гоголя, 2005. - 198 с. 2. Безносюк О. О. Педагогічні умови запровадження кредитно-модульної системи організації навчального процесу [навч.-метод. посіб.] / О. О. Безносюк, О. А. Прохоров, В. Л. Уліч; за заг. ред. Балабіна В. В. - К. : Інфодрук, 2007. - 20 с. 3. Гончаров С. М. Методи та технології навчання в кредитно-модульній системі організації навчального процесу: [навч.-метод. посіб.] / С. М. Гончаров, В. А. Гурин. - Рівне : НУВГП, 2010. 451 с. 4. Клочек Г. Про деякі проблеми «стратегії і тактики» реформування вищої педагогічної освіти / Г. Клочек // Освіта і управління. - 2007. - № 2. - С. 57-61. 5. Кондрашова Л. В. Высшая педагогическая школа и Болонский процесс / Лидия Валентиновна Кондрашова. - Кривой Рог : КДПУ, 2007. - 474 с. 6. Сікорський П. Проблеми вищої педагогічної освіти у світлі Булонської угоди / П. Сікорський // Вища школа. - 2008. -№ 1. - С. 26-35. 7. Стрельніков В. Ю. Педагогічні основи забезпечення особистісного і професійного розвитку студентів засобами інноваційних технологій навчання / В. Ю. Стрельніков. - Полтава : РВВ ПУСКУ, 2002. - 230 с. 